Chemical Technology Division

TREATMENT OF MERCURY CONTAMINATED OIL FROM THE MOUND SITE

K. T. Klasson

Topical Report

Date Published-November 2000

\author{
Prepared by \\ OAK RIDGE NATIONAL LABORATORY \\ Oak Ridge, Tennessee 37831 \\ managed by \\ UT-BATTELLE, LLC \\ for the \\ U.S. DEPARTMENT OF ENERGY \\ Under contract DE-AC05-00OR22725
}




\title{
Treatment of Mercury Contaminated Oil from the Mound Site
}

\author{
K. Thomas Klasson \\ Oak Ridge National Laboratory \\ Oak Ridge, Tennessee 37831-6226 \\ (865) 574-6813, klassonkt@ornl.gov
}

\section{Background}

Over one thousand gallons of tritiated oil, at various contamination levels, are stored in the Main Hill Tritium Facility at the Miamisburg Environmental Management Project (MEMP), commonly referred to as Mound Site. This tritiated oil is to be characterized for hazardous materials and radioactive contamination. Most of the hazardous materials are expected to be in the form of heavy metals, i.e., mercury, silver, lead, chromium, etc, but transuranic materials and PCBs could also be in some oils. Waste oils, found to contain heavy metals as well as being radioactively contaminated, are considered as mixed wastes and are controlled by Resource Conservation and Recovery Act (RCRA) regulations.

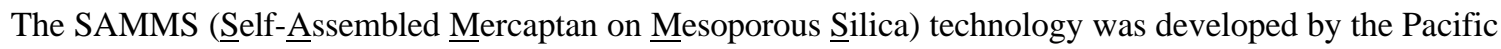
Northwest National Laboratory (PNNL) for removal and stabilization of RCRA metals (i.e., lead, mercury, cadmium, silver, etc.) and for removal of mercury from organic solvents. The SAMMS material is based on selfassembly of functionalized monolayers on mesoporous oxide surfaces. The unique mesoporous oxide supports provide a high surface area, thereby enhancing the metal-loading capacity.

SAMMS material has high flexibility in that it binds with different forms of mercury, including metallic, inorganic, organic, charged, and neutral compounds. The material removes mercury from both organic wastes, such as pump oils, and from aqueous wastes. Mercury-loaded SAMMS not only passes TCLP tests, but also has good long-term durability as a waste form because: 1) the covalent binding between mercury and SAMMS has good resistance in ion-exchange, oxidation, and hydrolysis over a wide $\mathrm{pH}$ range and 2) the uniform and small pore size of the mesoporous silica prevents bacteria from solubilizing the bound mercury.

\section{Materials and Methods}

The SAMMS material used in this study was received from PNNL as a fine white powder. This material is hydrophobic and mixes very well with oil. The following types of applications were implemented using the SAMMS material:

1. Bench-scale studies were performed at ORNL with contaminated oil from the Mound site. The purpose was to demonstrate the metal-capturing ability of SAMMS and to verify that the oil was suitable for filtration.

2. Bench-scale studies were performed at an independent laboratory with virgin vacuum pump oil spiked with high concentration of mercury and other metals. The purpose was to investigate SAMMS performance at elevated levels of contamination.

3. Large-scale demonstration was performed at the Mound site with contaminated oil. The purpose was to demonstrate the portability of the equipment, review operational procedures, and verify bench-scale results.

\section{Bench-scale Studies at ORNL}

Approximately one liter meteorology oil was shipped from the Mound Site. Analytical data provided by the Mound site indicated that the oil contained approximately $1 \mathrm{mg} / \mathrm{kg}$ of mercury (Table 1). 
Table 1. Analytical results provided by the Mound site for the meteorology oil.

\begin{tabular}{lcccccccccc}
\hline & \multicolumn{11}{c}{ Metal Concentration $(\mathrm{mg} / \mathrm{kg})$} \\
& $\mathrm{As}$ & $\mathrm{Ba}$ & $\mathrm{Cd}$ & $\mathrm{Cr}$ & $\mathrm{Cu}$ & $\mathrm{Pb}$ & $\mathrm{Se}$ & $\mathrm{Ag}$ & $\mathrm{Zn}$ & $\mathrm{Hg}$ \\
\hline OIL-DS-A & $<0.11$ & 0.27 & 0.14 & 0.26 & 3.5 & 0.2 & $<0.12$ & 0.09 & 4.0 & 0.98 \\
\hline
\end{tabular}

Fifty milliliter of this oil was combined with various amount of SAMMS material in 60-mL nominal-size polypropylene centrifuge tubes, vigorously shaken for a few minutes, and placed on rotary mixer for different length of time. At predetermined intervals, the tubes were removed and the content (oil + SAMMS) was filtered through Nalgene disposable filters (Cellulose Nitrate, $0.8 \mu \mathrm{m}$ pore size) via vacuum filtration.

A portion of the filtered oil was shipped via FedEx to Severn Trent Laboratories (previously Quanterra, Inc.), Earth City, Missouri, for metals analysis via EPA methods SW846 7471A (mercury) and SW846 6010B (other metals).

\section{Independent Laboratory Testing}

SAMMS material was shipped together with Nalgene disposable filters to an independent laboratory (Test America, Dayton, $\mathrm{OH}$ ). At the laboratory, virgin vacuum pump oil (Inland 19, Inland Vacuum Industries, Churchville, N.Y.) was spiked with metal standards (SPEX CertiPrep, Metuchen, NJ) to make seven different stock solutions

corresponding to

1. $2 \mathrm{mg} / \mathrm{kg}$ mercury,

2. $10 \mathrm{mg} / \mathrm{kg}$ mercury,

3. $50 \mathrm{mg} / \mathrm{kg}$ mercury,

4. $10 \mathrm{mg} / \mathrm{kg}$ cadmium,

5. $10 \mathrm{mg} / \mathrm{kg}$ lead,

6. $10 \mathrm{mg} / \mathrm{kg}$ chromium, and

7. $50 \mathrm{mg} / \mathrm{kg}$ each of mercury, cadmium, lead, and chromium.

250 milliliter of each stock solution was mixed with approximately $5 \mathrm{~g}$ of SAMMS material and stirred over night. The following day, a portion $(50 \mathrm{~g})$ of each solution was poured into containers with $50 \mathrm{~g}$ of Nochar 990 (Nochar, Inc., Indianapolis, IN), an oil stabilization agent. The remainder of the solutions was filtered using the Nalgene filters. Total metals analysis were performed on the filtrate and Toxicity Characteristics Leaching Procedure (TCLP) analysis were performed on samples taken from the stabilized oil.

\section{Large-scale Demonstration}

The large-scale treatment of mercury contaminated vacuum pump oil was performed at the Mound site. The oil was from the same source as the oil tested in ORNL's laboratory. The equipment used is shown in Figure 1 and a schematic of the system is shown in . The treatment system consisted of a 30-gallon mixing drum with a mixer, a pump, a filter module (0.5- $\mu \mathrm{m}$-pore filter), and a clean drum. Fifteen gallons of oil was mixed with $238 \mathrm{~g}$ of SAMMS for $22.5 \mathrm{~h}$. After mixing, 5 gallons of the oil was added to a 30 -gallon drum containing $35 \mathrm{lb}$ of Nochar 990. The remainder of the oil was pumped through the filter to a clean drum. The filter was drained and part of the sludge was added to a small container with Nochar 990. A schematic of the different experiments conducted on the large scale is shown in Figure 3. Total metals analysis was performed on the untreated oil, and metals leachability analysis (TCLP) was performed on the stabilized sludge solids and oil.

The amount of SAMMS needed for treatment of 15 gallons of oil was estimated from results obtained in the benchscale studies at ORNL with the same oil. The estimated amount ( $190 \mathrm{~g})$ was then increased by $25 \%$ to $238 \mathrm{~g}$ as safety measure. 


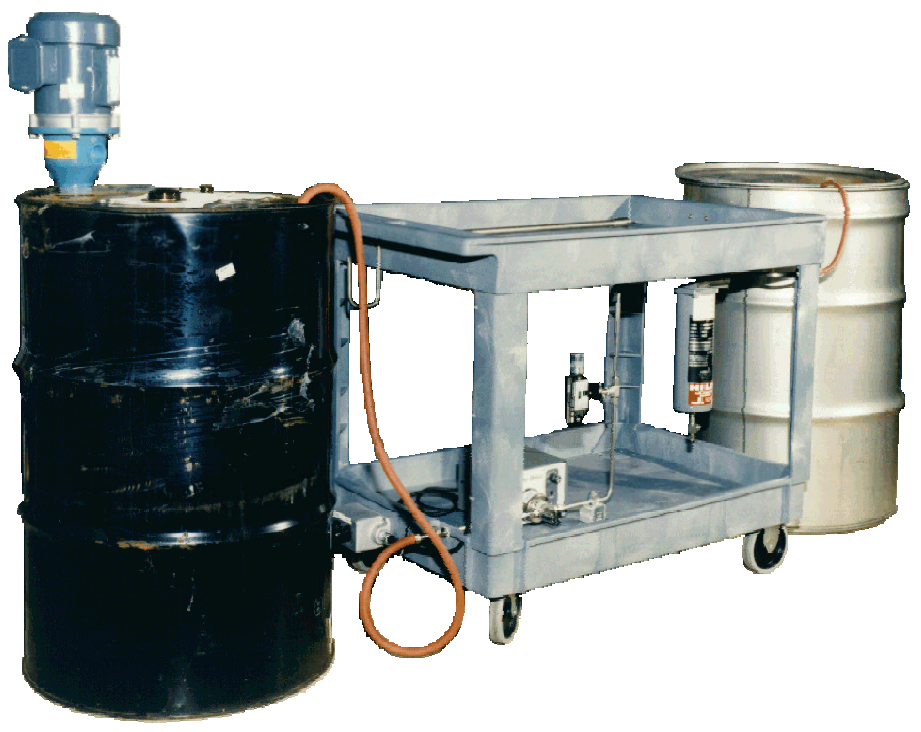

Figure 1. Photograph of the large-scale setup for treatment of contaminated oil.

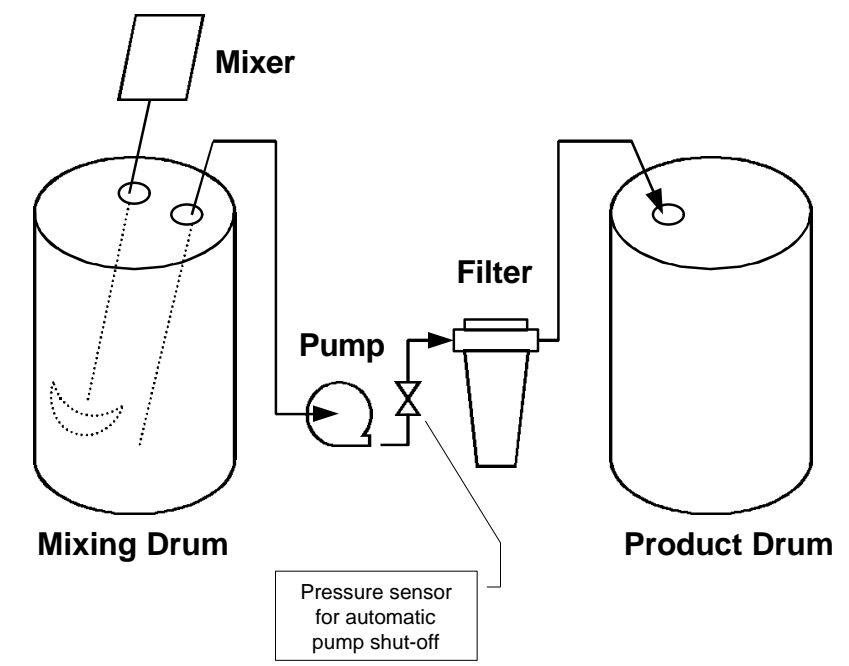

Figure 2. Simplified schematic of the treatment system used in the large-scale demonstration. 


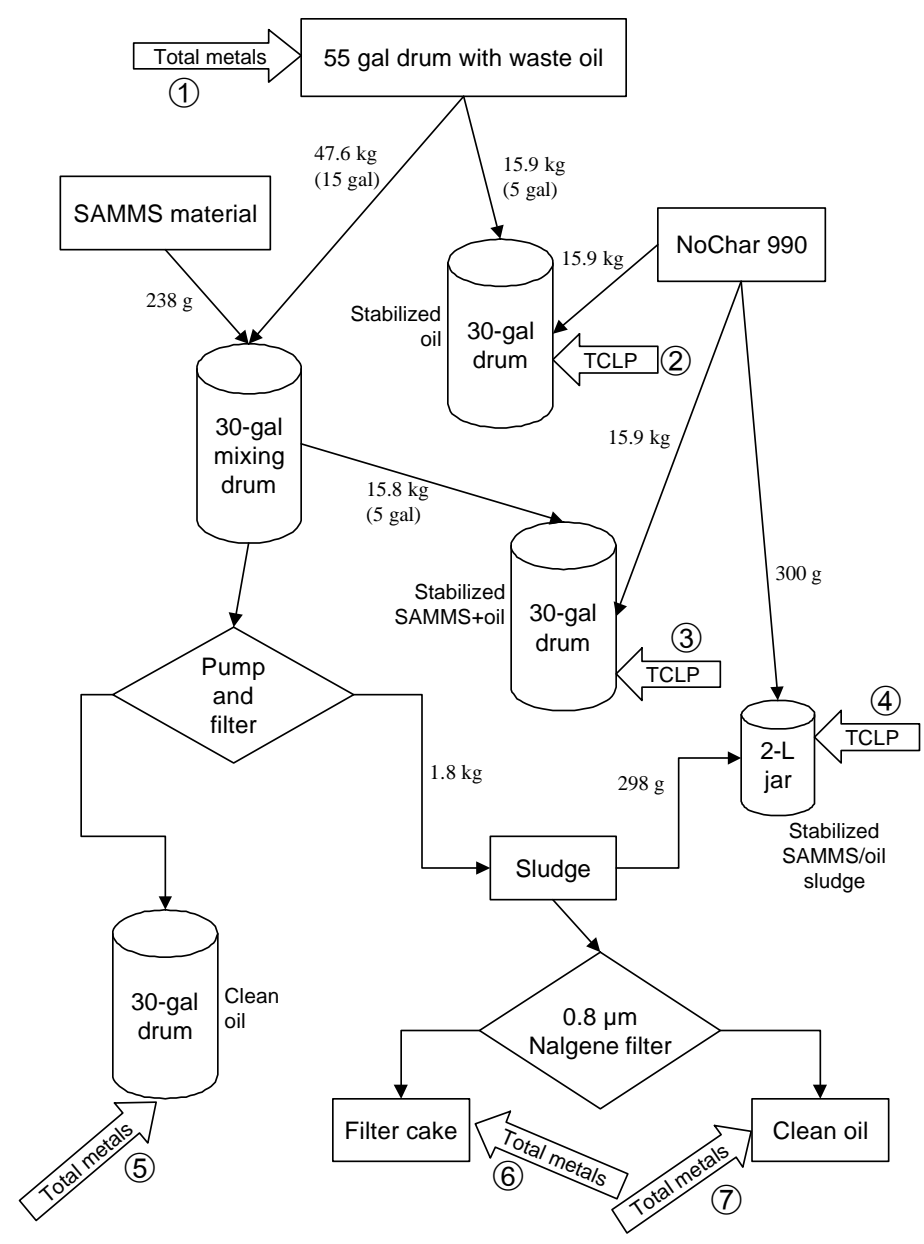

Figure 3. Schematic of large-scale demonstration activities.

\section{Results}

\section{Results from Bench-scale Studies at ORNL}

The oil and SAMMS material mixed well. For large applications, the SAMMS material is best mixed with the oil if it is added slowly to stirred oil. Filtration speed through the laboratory filters were approximately 10-15 min per 50 $\mathrm{mL}$ of oil. Full-scale filtration is anticipated to progress much faster if industrial-type filters are used. The analytical results, as well as the treatment parameters, are listed in Table 2.

Table 2. Treatment parameters and results in the studies. (Mercury results below 0.033 are the laboratory's estimated values. All results are in units of $\mathrm{mg} / \mathrm{kg}$.)

\begin{tabular}{|c|c|c|c|c|c|c|c|c|c|c|c|c|}
\hline $\begin{array}{l}\text { Contact Time } \\
\text { (h) }\end{array}$ & $\begin{array}{c}\text { Filtration } \\
\text { (yes/no) }\end{array}$ & $\begin{array}{c}\text { Amount SAMMS } \\
(\mathrm{g})\end{array}$ & Mercury & Arsenic & Lead & Selenium & Barium & Cadmium & Chromium & Copper & Silver & Zinc \\
\hline 24 & $\mathrm{y}$ & 0 & 0.65 & ND & $\mathrm{ND}$ & ND & ND & ND & ND & 2.4 & ND & ND \\
\hline 24 & $\mathrm{y}$ & 0.0524 & 0.05 & ND & ND & ND & ND & ND & ND & 1.7 & ND & ND \\
\hline 24 & $\mathrm{y}$ & 0.101 & 0.032 & ND & 0.19 & ND & ND & ND & ND & 1.1 & ND & ND \\
\hline 24 & $\mathrm{y}$ & 0.206 & 0.021 & ND & ND & ND & ND & ND & ND & 1.1 & ND & ND \\
\hline 24 & $\mathrm{y}$ & 0.5114 & ND & ND & ND & ND & ND & ND & ND & 0.51 & ND & ND \\
\hline 1 & $\mathrm{y}$ & 0.2046 & 0.082 & ND & ND & ND & ND & ND & ND & 1.6 & ND & ND \\
\hline 6 & $\mathrm{y}$ & 0.1991 & 0.032 & ND & ND & ND & ND & ND & ND & 1.4 & ND & ND \\
\hline 24 & $\mathrm{n}$ & 0.214 & 1.9 & ND & ND & ND & ND & ND & ND & 2 & ND & ND \\
\hline 48 & y & 0.2 & 0.011 & ND & ND & ND & ND & ND & ND & 1.1 & ND & ND \\
\hline 72 & $\mathrm{y}$ & 0.2164 & 0.012 & ND & ND & ND & ND & ND & ND & 1 & $\mathrm{ND}$ & ND \\
\hline 24 & $\mathrm{n}$ & 0 & 0.86 & ND & 0.31 & ND & ND & 0.2 & ND & 5.6 & $\mathrm{ND}$ & 2.4 \\
\hline 0 & $\mathrm{n}$ & 0 & 0.7 & ND & 0.2 & ND & ND & ND & ND & 4.2 & ND & 1.6 \\
\hline
\end{tabular}


As is noted in Table 2, the untreated unfiltered oil contained $0.7 \mathrm{mg} / \mathrm{kg}$. Filtered and unfiltered oil that had been in contact with the experimental equipment contained 0.65 and $0.86 \mathrm{mg} / \mathrm{kg}$, respectively. These results are the same within experimental error. It is important to note that simple filtration alone does not remove much (or any) of the mercury, however it does remove the zinc, the lead and some of the copper. The addition of SAMMS and prolonged mixing time improved the removal of mercury and copper.

SAMMS were added in amounts of 0 to $1 \%(\mathrm{w} / \mathrm{v})$ in these studies. Even the lowest amount of SAMMS added $(0.1 \%)$ removed mercury to $0.05 \mathrm{mg} / \mathrm{kg}$, which represents $0.0025 \mathrm{mg} / \mathrm{L}$ in a TCLP test. Increased amounts of SAMMS removed more of the remaining mercury, and non-detect levels were noted with $1 \%$ SAMMS addition. A summary of the results showing the effect of SAMMS addition may be seen in Figure 3. The "0\%" addition represents the concentration of mercury in oil that had been contacted with the equipment for $24 \mathrm{~h}$ and then filtered.

The effect of mixing time on the mercury removal efficiency has been displayed in Figure 5. As is noted, even a short contact time of $1 \mathrm{hr}$ removed much of the mercury, leaving approximately $0.08 \mathrm{mg} / \mathrm{kg}$ of mercury in the liquid. Longer mixing and contact time improved the performance and the data indicate that in $48 \mathrm{~h}$ equilibrium was reached. These result compares well with other data obtained in previous studies where it was noted that an excess of $24 \mathrm{~h}$ was needed to reach equilibrium. ${ }^{1}$

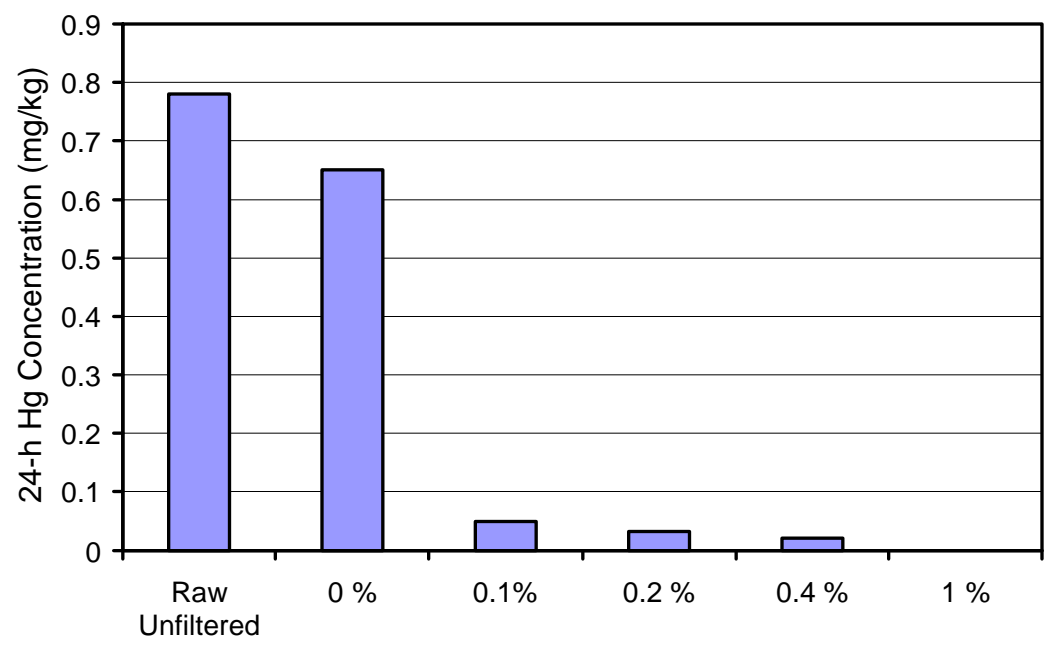

Amount of SAMMS (w/v)

Figure 4. Effect of SAMMS addition for a contact time of $24 \mathrm{~h}$.

\footnotetext{
${ }^{1}$ Klasson, K.T., P.A. Taylor, R.L. Cummins, and B.S. Evans, "Removal of Mercury and Tritium from DOE Waste Oils," Oak Ridge National Laboratory, ORNL/TM-13751, (March 1999).
} 


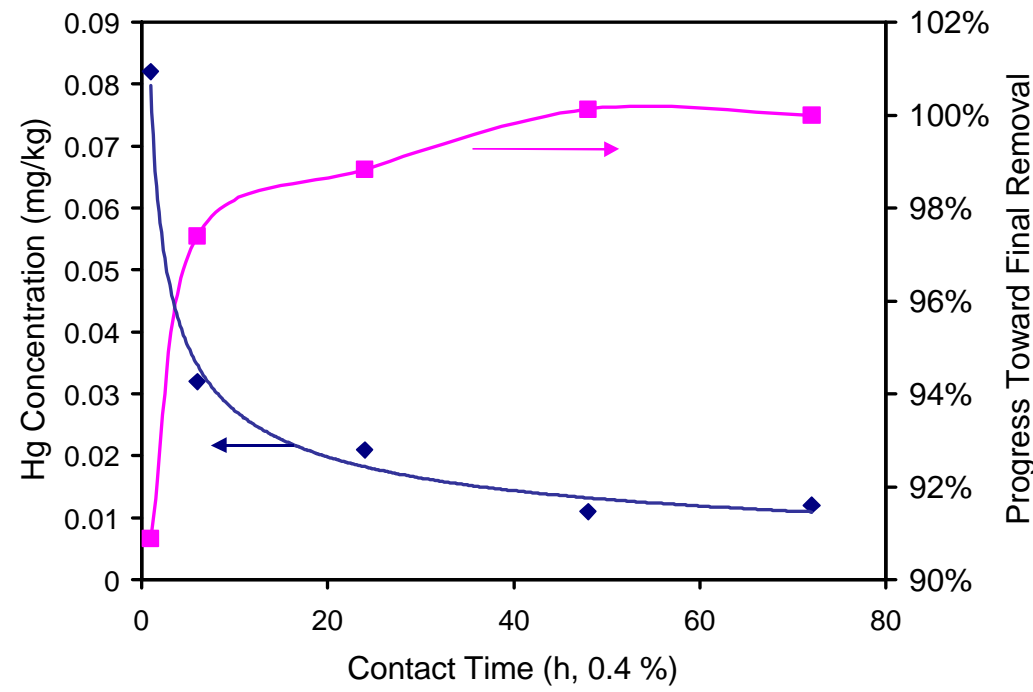

Figure 5. Effect of mixing time on the removal of mercury in oil. The SAMMS amount used was $0.4 \%(w / v)$ in all cases.

In order to estimated the amount of SAMS needed for the large-scale demonstration, the graph displaying the isotherm data in Figure 6 was constructed. The amount of SAMMS material needed for the demonstration was estimated based on the results obtained treatment depends on initial mercury concentration, treatment goal, and competing metals concentration. In Figure 6, we are showing the capacity of the SAMMS material as a function of 24-h mercury concentration in the oil. For example, if we desire to obtain $0.03 \mathrm{mg} / \mathrm{kg}$ of mercury in the oil at $24 \mathrm{~h}$, the mercury loading on the SAMMS material is approximately $0.25 \mathrm{mg} / \mathrm{g}$ (see Figure 6 , dashed line). If we were treating $47.6 \mathrm{~kg}$ of oil with $1 \mathrm{mg} / \mathrm{kg}$ of mercury, we need to remove approximately $1 \times 47.6=47.6 \mathrm{mg}$ of mercury. For that we need $47.6 \div 0.25=190 \mathrm{~g}$ of SAMMS material.

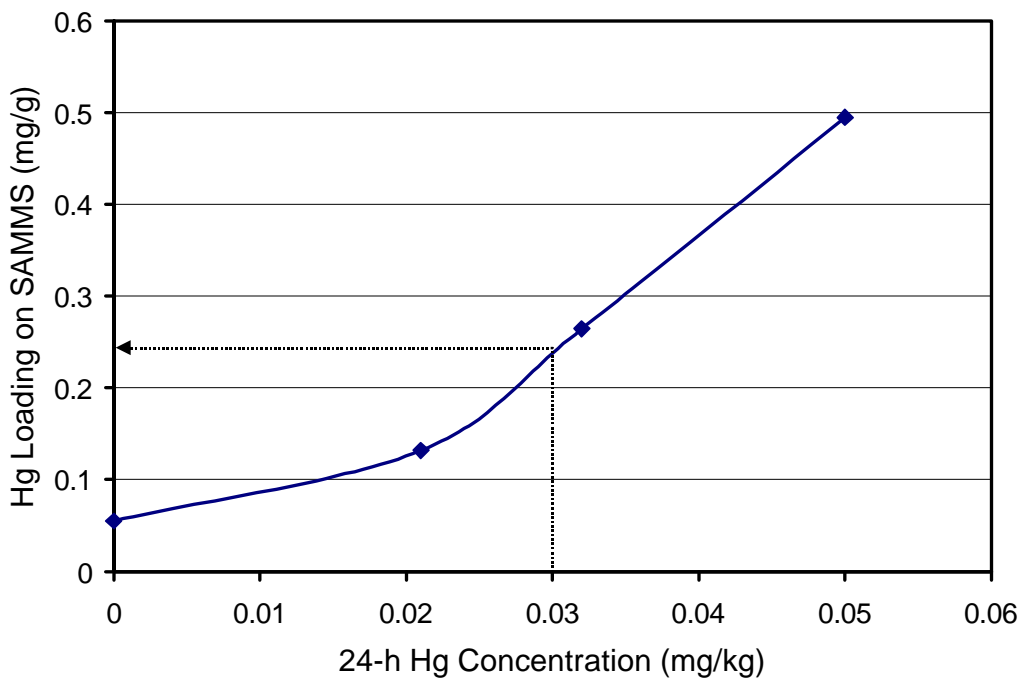

Figure 6. Isotherm result collected at 24 contact time.

\section{Results from Independent Laboratory Studies}

The SAMMS material was very effective in removing very high concentration of mercury from spiked vacuum pump oils. It was only in the experiment with the highest concentration of mercury that a small amount of mercury remained after treatment (see Figure 7). In that case, the final total mercury concentration in the oil was $1.88 \mathrm{mg} / \mathrm{kg}$, 
which potentially could exceed the Universal Treatment Standard ( $0.025 \mathrm{mg} / \mathrm{L}$ TCLP), but it would be lower than Resource Conservation and Recovery Act limits $(0.2 \mathrm{mg} / \mathrm{L}$ TCLP). TCLP analysis was not performed on the treated oil.

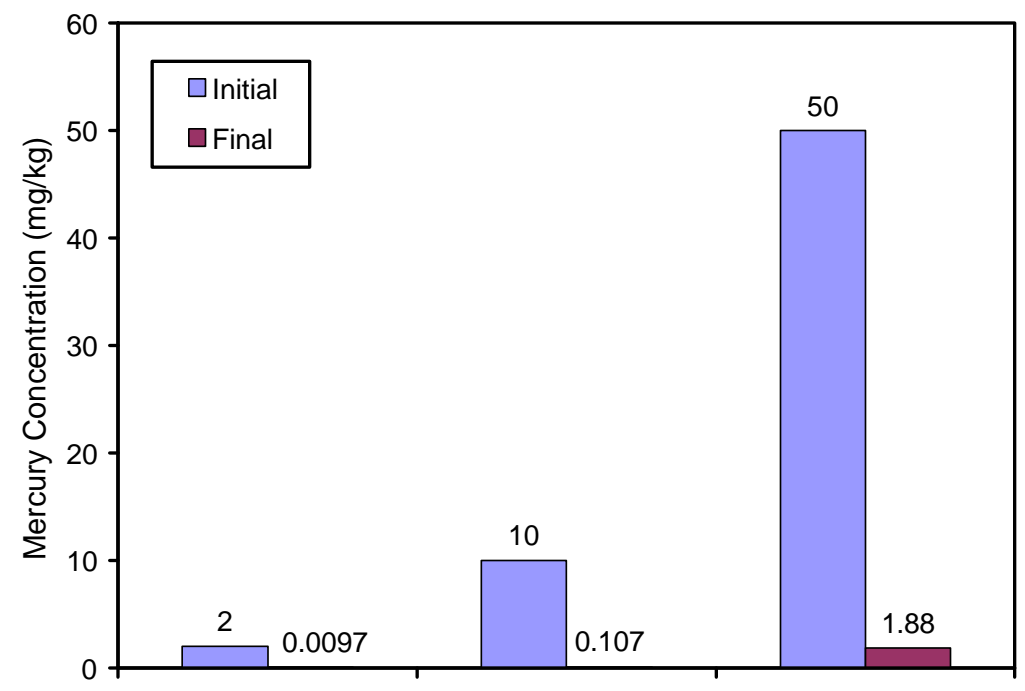

Figure 7. Results of bench-scale treatment of spiked vacuum pump oil. The numbers above the bars correspond to the measured total concentration of mercury. Two percent $(w / w)$ of SAMMS was added in each case.

The SAMMS material also proved very effective in removing the other metals (cadmium, lead, and chromium) when they each were the only metal contaminant present in the oil at $10 \mathrm{mg} / \mathrm{kg}$. The total metal concentration after treatment was below detection limits of the analytical method. When mercury was added in conjunction with all the other metal contaminates at $50 \mathrm{mg} / \mathrm{kg}$ for each metal, the SAMMS material was also very effective in sequestering all the metals. Only mercury and chromium were detected above detection limits in the treated oil (Figure 8).

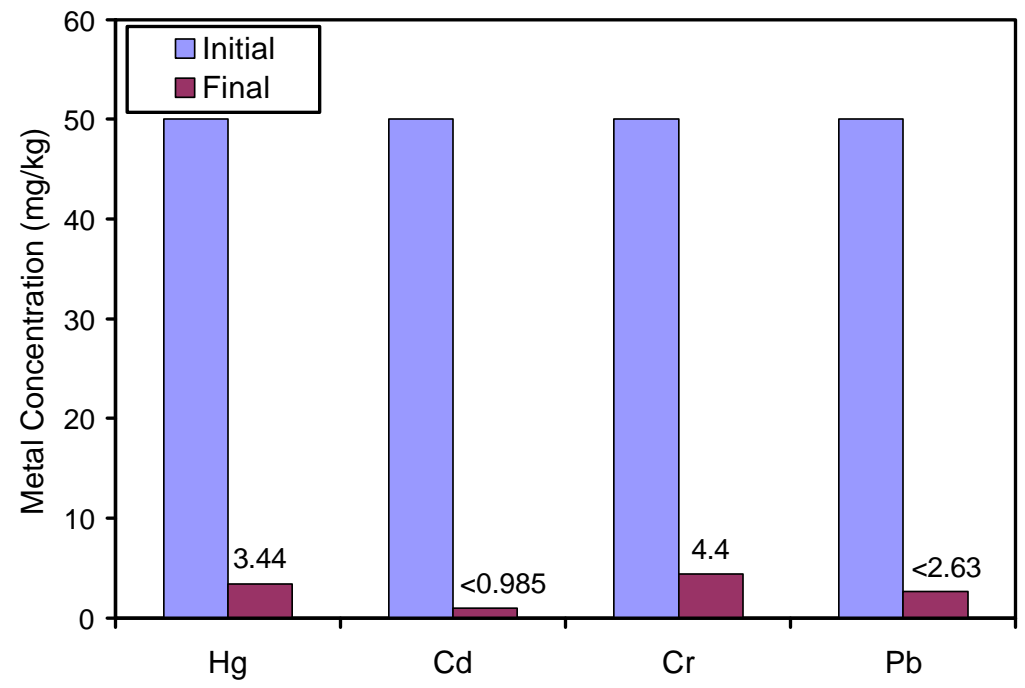

Figure 8. Treatment of mixed metals in spiked oil. The numbers above the bars correspond to the measured total concentration of the metal. Two percent (w/w) of SAMMS was added in each case. 
The most impressive results were obtained when the oil/SAMMS mixture was combined with Nochar 990 at a 1:1 weight ratio and TCLP analysis of the solidified oil was performed. In all cases, the results were below detection limits (Table 3). Testing with Nochar by itself did not result in all metals being below detection.

Table 3. Results from experiments demonstrating metals sequestration by SAMMS and matrix stabilization by Nochar.

\begin{tabular}{|c|c|c|c|}
\hline \multicolumn{2}{|c|}{ Metal Contaminant } & $\begin{array}{l}\text { Initial Concentration } \\
(\mathrm{mg} / \mathrm{kg})\end{array}$ & $\begin{array}{l}\text { TCLP Results } \\
(\mathrm{mg} / \mathrm{L})\end{array}$ \\
\hline \multicolumn{2}{|c|}{ Mercury } & 2 & $<0.001$ \\
\hline \multicolumn{2}{|c|}{ Mercury } & 10 & $<0.001$ \\
\hline \multicolumn{2}{|c|}{ Mercury } & 50 & $<0.001$ \\
\hline \multicolumn{2}{|c|}{ Cadmium } & 10 & $<0.15$ \\
\hline \multicolumn{2}{|c|}{ Lead } & 10 & $<0.4$ \\
\hline \multicolumn{2}{|c|}{ Chromium } & 10 & $<0.2$ \\
\hline \multirow{4}{*}{$\begin{array}{l}\text { Mixed } \\
\text { metals }\end{array}$} & Mercury & 50 & $<0.001$ \\
\hline & Cadmium & 50 & $<0.15$ \\
\hline & Lead & 50 & $<0.4$ \\
\hline & Chromium & 50 & $<0.2$ \\
\hline
\end{tabular}

\section{Results from the Large-scale Demonstration}

The results from the large-scale treatment are summarized in Table 4. As is noted, the SAMMS material removed mercury from $4.0 \mathrm{mg} / \mathrm{kg}$ to $0.72 \mathrm{mg} / \mathrm{kg}$. This final concentration could potentially exceed the Universal Treatment Standard ( $0.025 \mathrm{mg} / \mathrm{L}$ TCLP), but it would be lower than Resource Conservation and Recovery Act limits $(0.2 \mathrm{mg} / \mathrm{L}$ TCLP). It should be noted that the untreated oil contained $4 \mathrm{mg} / \mathrm{kg}$ of mercury, which is four times the amount we anticipated. Based on this new value, the amount of SAMMS needed to treat the volume of oil used in the demonstration is $762 \mathrm{~g}$ (see earlier discussions on how this is estimated). We only used $31 \%$ of this amount. Thus, it is not surprising that the final concentration was higher than expected. The importance of contact time is noted when comparing results obtained from samples collected at locations 5 and 6 (Figure 3 and Table 4). The total mercury concentration in these samples should theoretically be the same if there was no contact time dependency. The sludge provided to the laboratory was filtered several days after it was originally taken and estimated contact time for sample taken from location 6 was 5-7 days, compared to less than a day at sample location 5.

When SAMMS was first mixed with the oil over night and then stabilized with Nochar 990, the leachability of the mercury was below detection limits. When Nochar was applied to oil without SAMMS material, the leachability was very low but measurable. These result supports the results obtained with spiked oil in the independent laboratory study. Confirmation that the SAMMS material, and the system displayed in Figure 1, removed mercury from the oil is supported by the results from metals analysis of the SAMMS filter cake, where the metals accumulated. 
Table 4. Results of analysis of the different streams in the large-scale demonstration. The sample location numbers correspond to the labels in Figure 3.

\begin{tabular}{|c|c|c|c|c|c|}
\hline Sample Location & $\begin{array}{l}\text { Total Hg } \\
(\mathrm{mg} / \mathrm{kg})\end{array}$ & $\begin{array}{l}\text { TCLP Hg } \\
(\mathrm{mg} / \mathrm{L})\end{array}$ & $\begin{array}{l}\text { Total } \mathrm{Pb} \\
(\mathrm{mg} / \mathrm{kg})\end{array}$ & $\begin{array}{l}\text { Total Cd } \\
(\mathrm{mg} / \mathrm{kg})\end{array}$ & $\begin{array}{l}\text { Total Ba } \\
(\mathrm{mg} / \mathrm{kg})\end{array}$ \\
\hline (1) Untreated oil & 4.0 & & $<2.6$ & $<0.99$ & $<0.66$ \\
\hline (2) Oil stabilized with Nochar 990 & & 0.0032 & & & \\
\hline $\begin{array}{l}\text { (3) Oil treated with SAMMS and } \\
\text { stabilized with Nochar } 990\end{array}$ & & $<0.0010$ & & & \\
\hline $\begin{array}{l}\text { (4) SAMMS/oil sludge stabilized with } \\
\text { Nochar } 990\end{array}$ & & 0.0018 & & & \\
\hline (5) Oil treated with SAMMS & 0.72 & & $<2.6$ & $<0.99$ & $<0.66$ \\
\hline $\begin{array}{l}\text { (6) Laboratory-filtered SAMMS/oil } \\
\text { sludge }\end{array}$ & 0.12 & & $<2.6$ & $<0.99$ & $<0.66$ \\
\hline (7) SAMMS filter cake & 66.9 & & 6.5 & 3.1 & 5.34 \\
\hline
\end{tabular}

Some of most important lessons learned when operating the system depicted in Figure 1 was

- The mixing of a viscous fluid such as the oil with the type of drum mixer used generated a considerable amount of thermal energy, resulting in heating of the oil in the mixing drum. It is unknown how this effect performance of SAMMS and it may be operational issue to consider.

- After the mixing of oil and SAMMS was completed, the mixing motor was turned off before the slurry was pumped through the filter. During this pumping it was noted that the SAMMS material settled to the bottom of the drum rather quickly, thus not all the SAMMS material was pumped through the filter. The settling could be used, if it is desired to prolong the usage of the filter as the SAMMS material would not accumulate in this part of the system. 